\title{
A comparison of farmers' sow culling decisions and model recommendations
}

\author{
R.M.M. KRABBENBORG, A.A. DIJKHUIZEN \& R.B.M. HUIRNE \\ Department of Farm Management, Wageningen Agricultural University, Hollandseweg 1, \\ NL $6706 \mathrm{KN}$ Wageningen, Netherlands
}

Accepted 6 October 1989

\begin{abstract}
Sow culling data were analysed, using an economic replacement model. Average calculated losses of premature culling turned out to be Dfl. 124 per culled sow. With respect to the more economically based culling reasons, there was a striking resemblance between the actual decisions and the model recommendations for sows culled because of low productivity. Sows showing no heat, however, were culled too early after weaning and sows that failed to conceive too late.
\end{abstract}

Keywords: sows, culling decisions, economics

\section{Introduction}

In the Netherlands about $50 \%$ of the sows are replaced annually (Arkes et al., 1986). The average productive lifespan of the sows, therefore, is about 2 years or 4 litters only. Insufficient productive and reproductive performances are the most important removal reasons. Usually these sows are culled not because they are no longer able to produce, but because replacement gilts are expected to yield more. To optimize these culling decisions, an economic sow replacement model, named PorkCHOP, has been developed (Dijkhuizen et al., 1986). The model can be run on a personal computer, and is easily adjusted to individual farm conditions.

In the literature no attention has yet been paid to, whether there is any resemblance between farmers' actual sow culling decisions and economically optimum decisions provided by model calculations. Such an analysis is especially of interest to gain more insight into the underlying - economic - framework of the farmers' decision-making process. That may help to get a better idea of the potential benefits of computerized support, and can also contribute to a further improvement of the theoretical concept in modelling the economics of sow replacement decisions.

In this paper, results of such a combined analysis of field data and economic modelling are presented and discussed. 


\section{Materials and methods}

From an economic point of view, sows should be kept in the herd as long as their expected profit for the next parity is higher than the lifetime average return per parity from a replacement gilt. Based on this criterion the PorkCHOP model determines a sow's optimum lifespan, and then calculates the total extra profit to be expected from keeping her until that optimum and not replacing her immediately (Dijkhuizen et al., 1986). This total extra profit is called Retention-Pay-Off (RPO). The RPO is an economic index, to be used as a culling guide for individual sows within the herd. The higher the RPO index, the more valuable the sow. The index also represents the economic loss when a sow has to be culled prematurely. Moreover, it gives an indication for the number of days a farmer should wait when a sow does not conceive before deciding to cull her. A value below zero means that replacement is the more profitable option.

Standard Dutch record keeping systems for swine breeding herds do not provide individual sow performances and removal data, as required for the analysis in this paper. Access was available, however, to the database of the State Veterinary Faculty, which includes farms using the VAMPP herd health and management information system (Buurman et al., 1987). In total 12 farms had accurate and complete data from 1617 sows, culled during the years 1985 and 1986 . These farms were simulated in the PorkCHOP replacement model to calculate the RPO index for all the 1617 culled sows.

\section{Results}

In Table 1 the 1617 culled sows are classified by culling reason and for each reason the sows' calculated RPO index is presented. The average RPO index of culled sows

Table 1. Culled sows classified by culling reason and RPO index, calculated at the farms' normal time of weaning $(100 \%=1617$ culled sows)

\begin{tabular}{lccc}
\hline Culling reason & $\begin{array}{l}\text { in } \% \\
\text { of total }\end{array}$ & RPO index (Dfl) \\
\cline { 2 - 3 } & & average & $\% 0$ \\
Reproductive problems & 34.2 & 161 & 88 \\
- Failure to conceive & 25.2 & 153 & 87 \\
- No oestrus & 9.0 & 185 & 92 \\
Low productivity & 17.2 & 21 & 29 \\
- Old age & 11.0 & 14 & 37 \\
- Smail litters & 6.2 & 32 & 87 \\
Sickness/accidents & 16.0 & 147 & 69 \\
Mothering characteristics & 13.9 & 92 & 90 \\
Lameness/legg weakness & 10.5 & 183 & 79 \\
Others & 8.2 & 117 & 74 \\
Total & 100.0 & 124 & \\
\hline
\end{tabular}


turned out to be Df1. 124. So on an average, sows were (or had to be) removed too early. Only for about $25 \%$ of all culled sows the RPO index was below zero, indicating that replacement was the most profitable option.

In comparing model recommendations with actual decisions to cull sows because of low productivity (i.e. small litters and too old) there was a striking resemblance, as indicated by the average RPO index of only Dfl. 21 and the below-zero value for about $70 \%$ of these sows.

The most important reason for culling sows were the reproductive problems: no heat and failure to conceive. The RPO index for these sows was found to average Dfl. 161. The longer it takes to get these sows pregnant, the more urgent becomes the question: is the loss less when the farrowing interval is longer or when the sow is culled? By relating the value of the RPO index at the farms' normal time of weaning and the calculated financial loss of a delay in conception the PorkCHOP model gives an indication of the maximum allowable number of days for (re-)breeding. As shown in Table 2, the actual interval between first and last breeding for sows culled due to failure to conceive averages 71 days (or slightly more than 3 re-breedings), and hardly depends on parity number and productive quality of the sows concerned. The calculated allowable interval, however, averages 37 days only (or less than 2 rebreedings), and differs considerably across parity number and productive quality of the sows, as could be expected. Apparently, farmers pay too little attention to age and productivity in deciding whether to re-breed or to replace these sows. The same implies to sows which show no heat. Now, the calculated allowable interval exceeds the actual interval, however, especially for the younger and high producing sows.

Table 2. Actual and allowable number of days between first and last breeding, taking into account the sows' parity number and productive capacity.

\begin{tabular}{|c|c|c|c|c|c|c|}
\hline & \multicolumn{3}{|c|}{ Failure to conceive } & \multicolumn{3}{|c|}{ No heat } \\
\hline & $\begin{array}{l}\% \text { of } \\
\text { total }\end{array}$ & $\begin{array}{l}\text { actual } \\
\text { days }\end{array}$ & $\begin{array}{l}\text { allow. } \\
\text { days }\end{array}$ & $\begin{array}{l}\% \text { of } \\
\text { total }\end{array}$ & $\begin{array}{l}\text { actual } \\
\text { days }\end{array}$ & $\begin{array}{l}\text { allow. } \\
\text { days }\end{array}$ \\
\hline \multicolumn{7}{|l|}{ Parity } \\
\hline 1 & 25 & 64 & 55 & 45 & 24 & 54 \\
\hline $2-3$ & 30 & 73 & 51 & 34 & 20 & 47 \\
\hline$\geqq 4$ & 45 & 74 & 18 & 21 & 14 & 20 \\
\hline Total & 100 & 71 & 37 & 100 & 21 & 45 \\
\hline \multicolumn{7}{|c|}{ Rel. prod. level * } \\
\hline$<90$ & 31 & 65 & 17 & 29 & 18 & 18 \\
\hline $90-110$ & 38 & 75 & 36 & 37 & 21 & 39 \\
\hline$>110$ & 31 & 74 & 60 & 34 & 23 & 74 \\
\hline Total & 100 & 71 & 37 & 100 & 21 & 45 \\
\hline
\end{tabular}

* Number of pigs born alive in percentage of other sows in the same parity. 


\section{Final remarks}

The comparison between model recommendations and farmers' culling decisions has been made only for sows that were actually culled. Further research is of interest to investigate whether replacement of retained sows would have been the best decision. Moreover, it should be considered whether computerized decision support can help farmers to reduce income losses caused by sow removal. Further research is underway to widen the - theoretical — base for such a support (Huirne et al., 1988).

\section{Acknowledgements}

The authors are indebted to J. C. M. Vernooy (Department of Herd Health and Reproduction from the State Veterinairy Faculty in Utrecht) for providing the necessary farm and sow data.

\section{References}

Arkes, J.G., W.H.M. Baltussen, G.J.A. Ogink \& J. Schneider, 1986. Results on swine breeding herds in 1985. Swine Extension Service, Rosmalen and Institute of Agricultural Economics, The Hague (in Dutch).

Buurman, J., L.A.M.G. van Leengoed, A. Wierda, J.C.M. Vernooy \& P.C. van der Valk, 1987. VAMPP: a Veterinary Automated Management and Production control Program for swine breeding herds. I. Main features. The Veterinary Quarterly 9: 15-23.

Dijkhuizen, A.A., R.S. Morris \& M. Morrow, 1986. Economic optimization of culling strategies in swine breeding herds, using the 'PorkCHOP Computer Program'. Preventive Veterinary Medicine 4: 341-353.

Huirne, R.B.M., Th.H.B. Hendriks, A.A. Dijkhuizen \& G.W.J. Giesen, 1988. The economic optimization of sow replacement decisions by stochastic dynamic programming. Journal of Agricultural Economics 39: 426-438.

This synopsis is based on a student thesis entitled 'Een vergelijking van de vervangingsbeslissing bij zeugen onder model- en praktijkomstandigheden' by R.M.M. Krabbenborg, Department of Farm Management, Wageningen Agricultural University, Wageningen, 1987, 52 pp., 3 figs., 15 tables, 4 app., 25 refs., in Dutch. Available as paper copy (order R101, f 20 including postage) at: NARD, c/o Pudoc, P.O. Box 4, 6700 AA Wageningen (telex 45015 bluwg $\mathrm{nl}$ ). 